\title{
Local knowledge of medicinal plants in three artisanal fishing communities (Itapoá, Southern Brazil), according to gender, age, and urbanization
}

\author{
Adriana Heindrickson Cunha Merétika ${ }^{1,2}$, Nivaldo Peroni² e Natalia Hanazaki ${ }^{2,3}$
}

Recebido em 26/08/2009. Aceito em 10/02/2010

\begin{abstract}
Local knowledge of medicinal plants in three artisanal fishing communities (Itapoá, Southern Brazil), according to gender, age, and urbanization). This article analyzes some of the factors affecting the distribution of knowledge about medicinal plants of three artisanal fishing communities in Itapoá Municipality, in the state of Santa Catarina, Brazil. Ninety semi-structured interviews were performed, which resulted in 109 cited plant species. The sample included both men $(\mathrm{n}=46)$ and women $(\mathrm{n}=44)$, in different age categories: $18-40$ years old $(\mathrm{n}=18), 41-50(\mathrm{n}=21), 51-60(\mathrm{n}=28)$, and $61+$ years old $(\mathrm{n}=23)$, and in three different communities: Barra do Saí $(\mathrm{n}=17)$, Itapema do Norte $(\mathrm{n}=31)$ and Pontal do Norte $(\mathrm{n}=42)$. Leaves are the plant parts most used by the communities (62\%), and are obtained primarily through cultivation. Cordia curassavica (Jacq.) Roem. \& Schult. (Boraginaceae) is the species most cited in the interviews, locally known as 'erva-baleeira' or 'erva-de-baleia'. The elderly have greater knowledge of species, but no gender differences were noticed. Less knowledge of plants was noticed in the more urbanized area when compared to the less urbanized areas. The most used plants are not related to the most frequent ailments. Medicinal plant use is an important resource for the health of these fishing communities, but it is declining mostly due to the lack of interest on the part of the younger members, and to improved access to public health services.
\end{abstract}

Key words: ethnobotany, artisanal fisheries, traditional knowledge

RESUMO - (Conhecimento local sobre plantas medicinais em três comunidades de pescadores artesanais (Itapoá, sul do Brasil), de acordo com gênero, idade e urbanização). Este artigo analisa alguns dos fatores que afetam a distribuição do conhecimento sobre plantas medicinais em três comunidades de pescadores artesanais do Município de Itapoá, Santa Catarina, Brasil. Noventa entrevistas semi-estruturadas foram realizadas, o que resultou em 109 espécies de plantas citadas. A amostra foi composta por homens $(n=46)$ e mulheres $(n=44)$, em diferentes categorias de idade: 18-40 anos $(n=18)$, 41-50 $(\mathrm{n}=21), 51-60(\mathrm{n}=28)$, e 61 anos ou mais $(\mathrm{n}=23)$, e em três diferentes comunidades: Barra do Saí $(\mathrm{n}=17)$, Itapema do Norte $(\mathrm{n}=31)$ e Pontal do Norte $(\mathrm{n}=42)$. Folhas são as partes da plantas mais utilizadas $(62 \%)$, sendo obtidas principalmente por cultivo. Cordia curassavica (Jacq.) Roem. \& Schult. (Boraginaceae) é a espécie mais citada nas entrevistas, localmente chamada de "erva-baleeira" ou "erva-de-baleia". Os idosos têm um maior conhecimento sobre as espécies, mas não houve diferenças em relação ao sexo dos entrevistados. Um menor conhecimento sobre as plantas foi observado na área mais urbanizada, quando comparada com as áreas menos urbanizadas. As plantas mais utilizadas não estão relacionadas com as doenças mais freqüentes. As plantas medicinais são um recurso importante para a saúde dessas comunidades de pescadores, mas este conhecimento pode estar se deteriorando devido principalmente à falta de interesse dos membros mais jovens e à melhoria do acesso aos serviços públicos de saúde.

Palavras-chave: etnobotânica, pesca artesanal, conhecimento tradicional

\section{Introduction}

Fishing communities can be important sources of information for ethnobotany research (Hanazaki et al. 2009). These communities are directly connected to their natural environment and depend on it for survival, although rapid changes have been occurring due to increasing urbanization and higher tourism activity in coastal areas. According to Amorozo (2002), medicinal plant information is exchanged between individuals through a dynamic process of knowledge acquisition and loss. Case et al. (2005) stated that knowledge of medicinal plants is particularly vulnerable to loss due to the wider globalization and consequent acculturation process that these communities experience. Therefore, it is important to study changing communities which find themselves at risk of losing some of their socially inherited traditions, such as the artisanal fishermen of coastal South and Southeastern Brazil.

Hamilton (2004) expressed concern about how medicinal plant knowledge, as well as its handling, extraction, and ecology, seems to be in rapid decline despite many recent studies focusing on medicinal plants. Regarding the Brazilian coastal fishing communities, this valuable knowledge tends to decline due to massive urbanization and tourism, and also partly due to the fact that younger members refuse to follow their parents' profession. The latter contributes to a decline in fishermen and is a consequence of the growing jobs which are considerably more attractive than fishing (Figueiredo $e t$ al. 1993; Hanazaki et al. 2000).

The factors interfering in knowledge and use of plant resources are outlined and discussed in several papers (Figueiredo et al. 1993; Hanazaki 2004; Voeks 2007). Gender is a widely observed factor in studies on knowledge distribution, and women tend to know more about medicinal plants than men (Voeks \& Leony 2004; Quinlan \& Quinlan 2007). Such influence is usually related to their work activities in backyards and homegardens, as well as to care for family health in general (Camou-Guerrero et al. 2008). These activities can explain a wider knowledge of medicinal plants among women than men.

Age is another frequent factor analyzed in ethnobotanical studies; the elders tend to have more knowledge of medicinal plants (Quinlan \& Quinlan 2007; Yineger et al. 2008), although not in all cases (Yineger et al. 2008; Da Silva \&

\footnotetext{
1 Universidade Federal de Santa Catarina, Programa de Pós-Graduação em Biologia Vegetal, Florianópolis, SC, Brasil

2 Universidade Federal de Santa Catarina, Departamento de Ecologia e Zoologia, Laboratório de Ecologia Humana e Etnobotânica, Florianópolis, SC, Brasil

3 Autor para correspondência: natalia@ccb.ufsc.br
} 
Proença 2008). According to Voeks (2007) people acquire more knowledge with age, which can explain the tendency of finding greater knowledge accumulation amongst the elders.

However, gender and age are not the only or the most relevant factors affecting the dynamic distribution of ethnobotanical knowledge in a given community. Hanazaki et al. (2000) mentioned the environment as an influence on the diversity of plant knowledge or use amongst a human population. Benz et al. (2000) and Case et al. (2005), based on Mexico and Manus Island studies, stated that a public health system may erode medicinal plant knowledge in local communities. These statements indicate that habitat destruction and the loss of traditions in various human societies, when facing the culture of urban and modern societies, are important factors in the reduction of an ethnobotanical repertoire.

Ethnobotanical studies in Brazil are concentrated in the Amazon Forest, Atlantic Forest of Southeastern Brazil, and Semi-Arid Caatinga, but there are not enough studies in other regions such as Southern Brazil. The ethnobotanical studies that focus on local fishermen and medicinal plants are usually related to communities with some degree of indigenous origin, such as the Caiçaras (Figueiredo et al. 1993; 1997; Rossato et al. 1999; Hanazaki et al. 2000; Begossi et al. 2002). In Southern Brazil, the Amerindian influence has been replaced by more recent immigrations, especially by the Azoreans in the $18^{\text {th }}$ century, Italians and Germans in the $19^{\text {th }}$ and $20^{\text {th }}$ centuries, all of which were supported by governmental policies in order to colonize the area. The communities studied in this research have been influenced by European cultures, mostly Azorean, and this characteristic is not usually addressed in ethnobotanical studies performed in Brazil. The influence of Azorean descendants is widespread along the Santa Catarina coast due to cultural traditions brought from the Azores and Madeira Islands, both under Portuguese occupation.

The primary objective of this article is to investigate the distribution of medicinal plant knowledge within artisanal fishing families in Itapoá, Santa Catarina, Southern Brazil. The distribution of medicinal plant knowledge according to the interviewees' gender and age is analyzed, and the existence of different uses according to some ecological characteristics of the medicinal plants is discussed. Spontaneous, pioneer, and native plants are expected to be more widely known. On the other hand, a wide variety of cultivated exotic plants is also expected due to the European ethnic origin of these communities (see also Melo et al. 2008 and Miranda \& Hanazaki 2008). Other objectives are to discuss whether different community characteristics are related to knowledge regarding different medicinal plants, and to analyze the relationship between the use of specific plants to treat illnesses and whether those illnesses occur often in the community. This final consideration is in order to discuss the importance of medicinal plants for healthcare maintenance in the communities.

\section{Methods}

The study was developed in three fishing communities in Itapoá municipality, on the Northern coast of the state of Santa Catarina, Southern Brazil.This area is located between $26^{\circ} 00^{\prime} 21^{\prime \prime} \mathrm{S}, 48^{\circ} 36^{\prime} 15^{\prime \prime} \mathrm{W}$ and $26^{\circ} 10^{\prime} 58^{\prime \prime} \mathrm{S}, 48^{\circ} 36^{\prime} 33^{\prime \prime} \mathrm{W}$, and has a territory of $257 \mathrm{~km}^{2}$. Itapoá municipality was founded in 1989 , although it was first occupied in the 1940 's by fishermen and small-scale farmers. Most inhabitants have European ascendance, and this region is known as a coastal area with strong influence of Azorean colonists. The local vegetation has three large formations: Atlantic rain forest, sand dune vegetation ("restinga"), and mangroves. The average annual temperature of the city is $20^{\circ} \mathrm{C}$, with a relative air humidity of $87 \%$, and an average annual precipitation around $1,900 \mathrm{~mm}$

Itapoá has nearly 11,866 inhabitants, with $97 \%$ of its population located in urban areas (IBGE 2005). The Human Development Index of the city (IDH-M) is 0.793 , which places the city in $762^{\text {nd }}$ place among 5,500 Brazilian cities (PNUD 2000). The economy of the municipality is based on tourism and real estate. Fishing was one of the main activities of the city, though it is currently declining. Fishing communities are located approximately 10-30 kilometers away from one another: Barra do Saí to the north, Itapema do Norte in a more central and urbanized area, and Pontal do Norte and Figueira do Pontal to the south. In this study the latter two were considered a single community due to their reduced size and the short distance between them.

Information about knowledge of medicinal plant use was obtained through semi-structured interviews after prior informed consent was obtained verbally. In order to define the sample, a prior survey of the number of community households was conducted, with the aid of a map of the area. Through systematic random sampling, 3 out of every 10 households mapped in the previous survey were included, in order to avoid bias. Thus, interviews were performed with a sample of $30 \%$ of the community households: 17 at Barra do Saí, 31 at Itapema do Norte, and 42 at Pontal do Norte, with a total of 90 interviewees (46 men and 44 women) between September 2006 and September 2007.

The questions asked during the interviews regarded the name of medicinal plants used, use indications, plant parts used, place or method of extraction, utilization, and how the interviewee acquired the knowledge about the cited plants. Socio-economic data (such as age and ascendance) and information regarding the most frequent family illnesses were also obtained through the interviews. The names of the illnesses or health problems were considered according to the interviewees' perceptions, and grouped according to similarity (e.g., "stomach problems", "stomach pain", and "indigestion" were grouped as digestive problems). No clinical diagnosis was made to confirm the responses of the interviews. However, three semi-structured interviews were additionally performed with the physicians in charge of the health stations that serve the communities, in order to elicit more information on frequent diseases and treatments.

The plants mentioned during the interviews were collected with the help of the interviewees, then dried and identified by comparison with the Curitiba City Herbarium specimens, and later deposited in the FLOR Herbarium of the Federal University of Santa Catarina (Universidade Federal de Santa Catarina-UFSC). Collected plants without reproductive traits were deposited in the Human Ecology and Ethnobotany Laboratory of UFSC as reference materials.

The importance of a given medicinal plant can be reflected by the multiplicity of medicinal uses cited and the relative popularity of this plant (Friedman et al. 1986). Relative popularity of the medicinal plants cited in the interviews was obtained through the number of citations of each plant divided by the number of citations of the most cited plant (Friedman et al. 1986). Comparisons between plants cited by men and women were statistically tested with the Mann-Whitney test (5\%) using BioEstat 3.0 (Ayres et al. 2003). Comparisons between richness of cited plants and Hurlbert's PIE diversity index (Probability of Interspecific Encounters, Hurlbert 1971) were done using EcoSim software (Gotelli \& Entsminger 2001), and the differences were considered statistically significant if the lower diversity value did not fit within the upper and lower confidence intervals of $95 \%$ probability. Hurlbert's PIE diversity index was chosen because it allows the comparison of samples with different sizes in a rarefaction curve and is less affected by sample size than other indices such 
as Shannon-Wiener. For the age comparisons, the categories of 18-30, 31$40,41-50,51-60$, and $60+$ years old were initially selected. However, due to the small number of interviewees in the younger age categories, these two were grouped into a single category of $18-40$ years old.

\section{Results and discussion}

A total of 109 species of plants were cited, belonging to 54 botanical families; with 56 species being cited more than once (Tab. 1). Asteraceae, Lamiaceae and Verbenaceae comprised $31 \%$ of the 109 cited species. Asteraceae has significant representation in other studies regarding medicinal plant knowledge in South America (Bennett \& Prance 2000; Hanazaki et al. 2000; Amorozo 2002; Vandebroek et al. 2004). Cordia curassavica (Jacq.) Roem. $\&$ Schult., locally called 'erva-baleeira' or 'erva-de-baleia', was cited in $6 \%$ of the interviews, followed by Baccharis trimera (Less.) DC. ('carqueja' or 'carqueja-do-brejo') and Plectranthus neochilus Schltr. ('boldo'), cited in 5\% of the interviews.

When considering multiple uses and relative popularity, Cuphea carthagenensis (Jacq.) J.F. Macbr. ('sete-sangrias') showed the highest relative popularity (4.09) and was indicated for six different uses, followed by $B$. trimera with four different uses (3.45), C. curassavica with three different uses (3.00), Plantago tomentosa Lam. ('tansagem' or 'tanchagem') with five uses (2.73), Mentha sp. ('hortelã') with four uses (2.18), P. neochilus with only two uses (1.64) and Cymbopogon citratus (DC.) Stapf ('cana-santa' or 'canade-cheiro') with three uses (1.50).

According to the interviewees, medicinal plants are obtained mainly through cultivation ( $49 \%$ of citations) and backyard collection (32\%). Extraction from forest environments accounts for $11 \%$ of citations. Among the species used, 54 are exotic and 55 are native, though only 15 native species were collected in the forest, as the others grow in ruderal or cultivated areas. No commercialization was noted for these medicinal plants in the communities, which indicates that plant extraction is small and sporadic, and only for local consumption. This suggests that there is no relevant medicinal plant extraction pressure on the local vegetation.

The most used parts of medicinal plants were the leaves ( $62 \%$ of citations). Each of the other plant parts was mentioned in less than $10 \%$ of citations. Pinto et al. (2006) cited the predominant use of leaves in rural communities in the Atlantic Forest; Bourdy et al. (2000) registered an overwhelming use of leaves in one Amazon community, and Medeiros et al. (2004) obtained the same results with a group of ranchers in the state of Rio de Janeiro. This may indicate a high utilization of leaves when compared to other plant parts that are not available throughout the year, such as flowers, fruits, and seeds. The life form of plants cited as the most used was herb (62\%), which decreased the proportion of stems used when compared to plant leaves.

Medicinal plants are used as teas $(63 \%)$, dyes (12\%), syrup (6\%) and in bottles locally known as 'garrafadas'
$(5 \%)$. Teas are mostly made by decoction, which agrees with the research findings of Bourdy et al. (2000), Amorozo (2002) and Medeiros et al. (2004). The plants are prepared in the household, with little control over measurements and amounts used, with a few exceptions which may cause problems such as intoxication. It is also important to notice that some cited plants may present toxicity if used internally or prepared in elevated concentrations. For example, 'aveloz' (Euphorbia tirucalli L.) and 'confrei' (Symphytum officinale L.) are both dangerous and inappropriate for oral use (Lorenzi \& Matos 2002).

Some confusion resulted from the same popular name being given to different plant species, which may induce one to use a plant without the desired substance or maybe even use a dangerous plant (Lorenzi \& Matos 2002). For example, the species P. neochilus and Vernonia condensata Baker were both noted by some interviewees as 'boldo', usually associated with the species Peumus boldus Molina. The utilization of other popular names for the two cited species - 'boldo-gambá' for P. neochilus and 'boldo-baiano' for $V$. condensata - may reduce or avoid confusion when identifying the involved species.

The plants cited are used to treat 73 illnesses, of which $19 \%$ are digestive problems, $16 \%$ are skin conditions, and $14 \%$ are respiratory illnesses. Digestive and respiratory problems are the most frequently treated with medicinal plants according to many studies done on several ethnic groups in various locations around the globe (Bennett \& Prance 2000; Almeida \& Albuquerque 2002; Amorozo 2002; Di Stasi et al. 2002, Shrestha \& Dhillion 2003, Pieroni \& Quave 2005). However, the most frequent illnesses cited by the interviewees were osteo-muscular problems such as body aches and rheumatism, as well as high blood pressure. These data show that the most frequent illnesses are not treated with medicinal plants. Interviewees over 60 years old knew a larger number of species to treat urinary problems (33\%), though these problems were not cited as frequent. The younger people (18-40 years old) mostly knew species to treat digestive problems $(22 \%)$.

Comparing the richness of medicinal plants cited by both men and women, women know more medicinal plants than men, for they cited a higher average number of plants as well as a higher average number of citations. However, statistically the difference is not significant (Mann-Whitney on 109 species, $U=2739.5$ and $p=0.9970$ ) even if plants cited only once are ignored (Mann-Whitney on 56 species cited more than once, $U=602.5$ and $\mathrm{p}=0.8843$ ). When comparing the distribution of citations with Hurlbert's PIE, there is a significant difference in which women know a wider diversity of plants (Tab. 2). Other papers show greater knowledge among women (Figueiredo et al. 1993; Voeks \& Leoni 2004). However, Hanazaki et al. (2000) registered two Caiçara communities in which men knew more medicinal plants than women. This could be explained by the closer contact between the men and the forest, when compared to 
Table 1. Medicinal plants cited at least twice in 90 interviews performed in the city of Itapoá, Santa Catarina, Brazil ${ }^{1}$

\begin{tabular}{|c|c|c|c|c|c|}
\hline $\begin{array}{l}\text { FAMILY } \\
\text { Scientific name }\end{array}$ & $\begin{array}{l}\text { Citations } \\
\text { number }\end{array}$ & Prescriptions & Obtention & Parts used & origin \\
\hline \multicolumn{6}{|l|}{ ADOXACEAE } \\
\hline $\begin{array}{l}\text { Sambucus australis Cham. \& Schltdl. } \\
\text { ALISMATACEAE }\end{array}$ & 3 & Skin allergy, cough, blood cleaning & $\mathrm{C}, \mathrm{Q}$ & $\mathrm{F}$ & native \\
\hline $\begin{array}{l}\text { Echinodorus grandiflorus (Cham. \& } \\
\text { Schltdl.) Micheli }\end{array}$ & 9 & Cystitis, kidney stone, bladder problems & $\mathrm{C}, \mathrm{Q}$ & $\mathrm{L}$ & native \\
\hline \multicolumn{6}{|l|}{ AMARANTHACEAE } \\
\hline $\begin{array}{l}\text { Alternanthera dentata (Moench) } \\
\text { Stuchlik ex R.E. Fr. }\end{array}$ & 2 & Infections & Q & $\mathrm{L}$ & native \\
\hline $\begin{array}{l}\text { Chenopodium ambrosioides L. } \\
\text { ANACARDIACEAE }\end{array}$ & 2 & Louse, vermin & $\mathrm{C}, \mathrm{Q}$ & $\mathrm{L}, \mathrm{S}$ & native \\
\hline $\begin{array}{l}\text { Schinus terebinthifolia } \text { Raddi } \\
\text { APIACEAE }\end{array}$ & \multicolumn{4}{|c|}{ APIACEAE } & native \\
\hline \multicolumn{6}{|l|}{ ARISTOLOCHIACEAE } \\
\hline \multicolumn{6}{|l|}{ ASPHODELACEAE } \\
\hline $\begin{array}{l}\text { Aloe arborescens Mill. } \\
\text { ASTERACEAE }\end{array}$ & \multicolumn{4}{|c|}{ ASTERACEAE } & exotic \\
\hline Achyrocline satureioides (Lam.) DC. & 12 & Indigestion, stomach problems, stomach pain & Q & $\mathrm{F}$ & native \\
\hline Ageratum conyzoides $\mathrm{L}$. & 9 & Leg pain, back pain, body aches, rheumatism, inflammation & $\mathrm{C}, \mathrm{Q}$ & $\mathrm{T}, \mathrm{L}, \mathrm{W}$ & native \\
\hline Artemisia absinthium $\mathrm{L}$. & 4 & Food poisoning, stomach problems, stomach pain & $\mathrm{C}$ & $\mathrm{L}$ & exotic \\
\hline Baccharis trimera (Less.) DC. & 19 & $\begin{array}{l}\text { Stomach pain, kidney problems, weight loss and high } \\
\text { cholesterol }\end{array}$ & Q,M & $\mathrm{L}$ & native \\
\hline Mikania cordifolia (L. f.) Willd. & 3 & Bronchitis, cough & M & $\mathrm{L}$ & native \\
\hline Porophyllum ruderale (Jacq.) Cass. & 8 & Inflammation, rheumatism, swelling & $\mathrm{C}, \mathrm{Q}$ & $\mathrm{L}, \mathrm{W}$ & native \\
\hline Solidago chilensis Meyen & 3 & Muscle pain, body aches, rheumatism & Q,M & $\mathrm{L}, \mathrm{F}$ & native \\
\hline Sphagneticola trilobata (L.) Pruski & 4 & Mosquito bites, bruises, rheumatism, body ache & Q & $\mathrm{L}, \mathrm{F}$ & native \\
\hline Tanacetum vulgare $\mathrm{L}$. & 2 & Infection, pains, stomach problems & $\mathrm{C}, \mathrm{D}$ & $\mathrm{R}, \mathrm{L}$ & exotic \\
\hline Vernonia polyanthes Less. & 3 & Leg pains, inflammation, rheumatism & $\mathrm{C}, \mathrm{Q}$ & $\mathrm{L}, \mathrm{F}$ & native \\
\hline \multicolumn{6}{|l|}{ BORAGINACEAE } \\
\hline $\begin{array}{l}\text { Cordia curassavica (Jacq.) Roem. } \\
\& \text { Schult. }\end{array}$ & 22 & Inflammation, rheumatism, leg pain, back pain, body ache & $\mathrm{C}, \mathrm{Q}$ & $\mathrm{L}$ & native \\
\hline $\begin{array}{l}\text { Symphytum officinale L. } \\
\text { COMBRETACEAE }\end{array}$ & \multicolumn{4}{|c|}{ COMBRETACEAE } & exotic \\
\hline $\begin{array}{l}\text { Terminalia catappa } \mathrm{L} . \\
\text { CONVOLVULACEAE }\end{array}$ & \multicolumn{4}{|c|}{ CONVOLVULACEAE } & exotic \\
\hline \multicolumn{2}{|l|}{ COSTACEAE } & Kidney problem, cough, bruises & $\mathrm{C}, \mathrm{M}$ & W & exotic \\
\hline $\begin{array}{l}\text { Costus spicatus (Jacq.) Sw. } \\
\text { CRASSULACEAE }\end{array}$ & \multicolumn{2}{|c|}{ CRASSULACEAE } & $\mathrm{C}, \mathrm{Q}$ & $\mathrm{T}, \mathrm{L}$ & native \\
\hline $\begin{array}{l}\text { Kalanchoe delagoensis Eckl. \& Zeyh. } \\
\text { CUCURBITACEAE }\end{array}$ & \multicolumn{4}{|c|}{ CUCURBITACEAE } & exotic \\
\hline $\begin{array}{l}\text { Sechium edule (Jacq.) Sw. } \\
\text { EQUISETACEAE }\end{array}$ & \multicolumn{4}{|c|}{ EQUISETACEAE } & exotic \\
\hline Equisetum hyemale L. & 3 & Kidney problem, bladder problem, kidney pain & $\mathrm{P}, \mathrm{C}$ & $\mathrm{T}, \mathrm{L}, \mathrm{W}$ & native \\
\hline \multicolumn{6}{|l|}{ EUPHORBIACEAE } \\
\hline Euphorbia tirucalli $\mathrm{L}$. & 4 & Leukemia, cancer, warts, kidney problems, cicatrizant & $\mathrm{C}$ & $\mathrm{T}, \mathrm{O}$ & exotic \\
\hline \multicolumn{6}{|l|}{ FABACEAE } \\
\hline Bauhinia candicans Benth. & 7 & Kidney problems, kidney stones, cystitis, diabetes & $\mathrm{C}, \mathrm{Q}, \mathrm{M}$ & $\mathrm{L}$ & native \\
\hline
\end{tabular}


Tabela 1. Continuation.

\begin{tabular}{|c|c|c|c|c|c|}
\hline $\begin{array}{l}\text { FAMILY } \\
\text { Scientific name }\end{array}$ & $\begin{array}{l}\text { Citations } \\
\text { number }\end{array}$ & Prescriptions & Obtention & Parts used & origin \\
\hline \multicolumn{6}{|l|}{ LAMIACEAE } \\
\hline Melissa officinalis L. & 2 & Sedative, ringworm, inflammation, hypertension, flu & $\mathrm{C}$ & $\mathrm{L}$ & exotic \\
\hline Mentha sp. & 12 & Sedative, flu, vermin, stomach ache & $\mathrm{C}$ & $\mathrm{L}$ & exotic \\
\hline Plectranthus barbatus Andrews & 6 & Hangover, stomach ache, stomach problems & $\mathrm{C}, \mathrm{Q}$ & $\mathrm{L}$ & exotic \\
\hline Plectranthus neochilus Schltr. & 18 & Stomach ache, stomach problems, indigestion & $\mathrm{C}, \mathrm{Q}$ & $\mathrm{L}$ & exotic \\
\hline \multicolumn{6}{|l|}{ LAURACEAE } \\
\hline Persea americana Mill. & 4 & Cholesterol, diabetes, kidney problems, constipation & $\mathrm{C}, \mathrm{Q}, \mathrm{M}$ & $\mathrm{L}, \mathrm{U}$ & exotic \\
\hline \multicolumn{6}{|l|}{ LYTHRACEAE } \\
\hline $\begin{array}{l}\text { Cuphea carthagenensis (Jacq.) J.F. } \\
\text { Macbr. }\end{array}$ & 15 & $\begin{array}{l}\text { Hypertension, diabetes, circulation problems, liver } \\
\text { problems, kidney problems }\end{array}$ & $\mathrm{C}, \mathrm{Q}$ & $\mathrm{L}, \mathrm{W}$ & native \\
\hline \multicolumn{6}{|l|}{ MALVACEAE } \\
\hline Sida rhombifolia $\mathrm{L}$. & 2 & Blood cleaning, fatigue & Q & W & native \\
\hline \multicolumn{6}{|l|}{ MYRTACEAE } \\
\hline Psidium guajava $\mathrm{L}$. & 6 & Diarrhea, stomach ache, vermin & $\mathrm{C}$ & $\mathrm{L}$ & native \\
\hline Syzygium cumini (L.) Skeels & 8 & Diabetes, cholesterol & $\mathrm{C}$ & $\mathrm{L}$ & exotic \\
\hline \multicolumn{6}{|l|}{ PASSIFLORACEAE } \\
\hline Passiflora alata Curtis & 2 & Sedative, hypertension & Q & $\mathrm{U}$ & native \\
\hline \multicolumn{6}{|l|}{ PHYLLANTHACEAE } \\
\hline Phyllanthus niruri $\mathrm{L}$. & 14 & Kidney infection, kidney problems, kidney stones, diuretic & $\mathrm{C}, \mathrm{Q}$ & $\mathrm{L}, \mathrm{W}$ & native \\
\hline Phyllanthus tenellus Roxb. & 4 & Kidney problems, kidney stones, diuretic & $\mathrm{C}, \mathrm{Q}$ & $\mathrm{L}, \mathrm{W}$ & native \\
\hline Petiveria alliacea $\mathrm{L}$. & 7 & Inflammation & $\mathrm{C}, \mathrm{Q}$ & $\mathrm{L}$ & native \\
\hline \multicolumn{6}{|l|}{ PHYTOLACCACEAE } \\
\hline Plantago major $\mathrm{L}$. & 2 & Infections, sore throat & $\mathrm{C}$ & $\mathrm{L}$ & exotic \\
\hline Plantago tomentosa Lam. & 12 & $\begin{array}{l}\text { Throat problems, throat infection, cystitis, infections, } \\
\text { inflammation, body ache }\end{array}$ & $\mathrm{C}, \mathrm{Q}$ & $\mathrm{L}, \mathrm{W}$ & native \\
\hline \multicolumn{6}{|l|}{ POACEAE } \\
\hline Cymbopogon citratus (DC.) Stapf & 11 & Sedative, flu, shortness of breath & $\mathrm{C}$ & $\mathrm{L}$ & exotic \\
\hline \multicolumn{6}{|l|}{ POLYGALACEAE } \\
\hline Polygala paniculata $\mathrm{L}$. & 7 & Bruises, arm pains, body aches, bumps, rheumatism & $\mathrm{C}, \mathrm{Q}$ & $\mathrm{R}, \mathrm{L}$ & native \\
\hline \multicolumn{6}{|l|}{ RUBIACEAE } \\
\hline Coffea arabica $\mathrm{L}$. & 3 & Pneumonia, cicatrizant & $P$ & $\mathrm{U}$ & exotic \\
\hline Richardia brasiliensis Gomes & 3 & Bronchitis, flu & $\mathrm{C}, \mathrm{M}$ & $\mathrm{R}, \mathrm{L}$ & native \\
\hline \multicolumn{6}{|l|}{ RUTACEAE } \\
\hline Citrus aurantifolia (Christm.) Swingle & 4 & Flu, pneumonia, diarrhea & $\mathrm{P}, \mathrm{C}, \mathrm{Q}$ & $\mathrm{L}, \mathrm{U}$ & exotic \\
\hline Ruta graveolens $\mathrm{L}$. & 3 & Cough, vermin, ear ache & $\mathrm{C}$ & $\mathrm{L}$ & exotic \\
\hline \multicolumn{6}{|l|}{ SMILACACEAE } \\
\hline Smilax brasiliensis Spreng. & 3 & Leg pains, blood cleaning, vermin & Q & $\mathrm{L}$ & native \\
\hline \multicolumn{6}{|l|}{ SOLANACEAE } \\
\hline Solanum americanum Mill. & 3 & Vermin & $\mathrm{C}, \mathrm{Q}$ & $\mathrm{L}$ & native \\
\hline \multicolumn{6}{|l|}{ VERBENACEAE } \\
\hline Aloysia triphylla Royle & 2 & Flu, sedative & $\mathrm{C}$ & $\mathrm{L}$ & exotic \\
\hline Lantana canescens Kunth & 4 & Bruises, diuretic, tooth ache & $\mathrm{Q}, \mathrm{M}$ & $\mathrm{L}, \mathrm{F}$ & native \\
\hline Lippia alba (Mill.) N.E. Br. & 7 & Sedative, flu, fever, discomfort & $\mathrm{C}, \mathrm{Q}$ & $\mathrm{L}$ & native \\
\hline Stachytarpheta cayennensis (Rich.) Vahl & 3 & Cholesterol, liver problems, stomach pains, cancer & $\mathrm{C}, \mathrm{Q}$ & $\mathrm{L}$ & native \\
\hline Verbena litoralis Kunth & 4 & $\begin{array}{l}\text { Stomach problems, liver problems, stomach pain, } \\
\text { leukemia, cholesterol }\end{array}$ & Q & $\mathrm{L}$ & native \\
\hline
\end{tabular}

1 - Obtention: C- cultivated, D - donated, M - collected in fields, P - purchased, Q - collected in backyards; Parts usedt: F - flower, L - leaf, R - root, S - seed, U

- fruit, $\mathrm{T}$ - stalk, $\mathrm{W}$ - entire plant, $\mathrm{O}$ - other). The prescriptions were listed according to the interviewees' perceptions. 
Table 2. Comparison of cited plants according to gender for 90 interviews performed in fishing communities in Itapoá city, Santa Catarina, Brazil.

\begin{tabular}{lcc}
\hline & Men & Women \\
\hline Average plant richness plants per interview & $3.50 \pm 2.63$ & 109 \\
Number of citations & 46 & 109 \\
Number of interviews & 68 & 44 \\
Number of species cited & 878 \\
Hurlbert's PIE (confidence interval) & 0.97469 & $0.98238(0.97981-0.98470)$ \\
\hline
\end{tabular}

women. In Itapoá this closeness between men and the forest environment was not present, which could be related to the predominance of the use of medicinal plants found near the households.

Men exclusively cited 22 plant species, 9 of which are obtained by cultivation and 6 of which are collected in backyards. Women exclusively cited 41 plant species, 26 of which obtained by cultivation and 5 of which are collected in backyards. In these communities it is customary of women to grow small gardens or plantations around the household, which could explain the higher number of cultivated species. Forest extraction of medicinal plants was seldom cited. Fonseca-Kruel \& Peixoto (2004) pointed out the influence of other cultures as an indication of the low use of native species among artisanal fishermen in a marine reserve in the city of Arraial do Cabo, in the state of Rio de Janeiro, Brazil. A similar situation related to the origin of the communities may be occurring in Itapoá. Only one interviewee claimed indigenous origins and 10 other interviewees claimed Portuguese/Amerindian origins; all other interviewees claimed to be exclusively European. None of the origins showed knowledge discrepancies; plants cited by people with Amerindian origins were also cited by people with European origins. Along with ascendance, fear of snakes was mentioned by several interviewees as interfering in forest collecting. This influences people to opt for collecting in backyards or cultivating other species with a similar medicinal effect. In the work of Voeks (1996) and Pinto et al. (2006) low utilization of medicinal Atlantic Forest plant resources was also noticed.

Some medicinal species have come from Europe and are used throughout the world, like Rosmarinus officinalis L. ('alecrim') and Chamomilla recutita (L.) Rauschert ('camomila') (Lorenzi \& Matos 2002). On the other hand, three of the most cited species are native (C. curassavica, $B$. trimera, and $P$. neochilus). These species are abundant, easily found and considered to be urban weeds, since there is no need for management in order to perpetuate them.

The younger interviewees knew fewer medicinal plants than the elderly, both in number of citations and in amount of known species (Tab. 3). Research worldwide shows that the elderly know more medicinal plants than their younger counterparts (Matavele \& Habib 2000; Begossi et al. 2002; Fonseca-Kruel \& Peixoto 2004; Case et al. 2005; Pinto et al. 2006; Pilla et al. 2006). However, the age difference is not entirely significant when analyzed with age categories. When comparing richness and Hurlbert's PIE within all four age categories, only the interviewees over 60 years old show different results (Tab. 3).

In these communities, $75 \%$ of citations mention that medicinal plant knowledge runs from mothers to children; in $20 \%$ of citations knowledge comes from elders such as other family members and acquaintances; and $6 \%$ of citations show medicinal plant knowledge coming from the television. Medicinal plant knowledge transmission occurs within the family environment from older to younger generations. This result differs from that of Pinto et al. (2006) which showed low knowledge transmission to younger family members in rural communities of the Atlantic Forest in the state of Bahia.

When comparing richness and Hurlbert's PIE within the communities, only Itapema do Norte showed significant differences; Barra do Saí and Pontal do Norte showed no differences regarding richness and diversity of cited plants (Tab. 4). The more urban communities tend to have broader access to public health services as well as dwindling contact with backyards and forest areas. Barra do Saí is the smallest community and showed a similar citation average to Pontal do Norte, and a higher species average than all other communities. Barra do Saí is also the oldest occupation site of Itapoá (approximately 100 years old), which can explain the greater knowledge of plants. Until 1989, upon the municipality's emancipation, there were no public health services available to the population, and only homemade treatments were available. Information exchange within the community is favored by the small physical area and the consequent higher contact between community members. The community is currently being urbanized and it is becoming one of the main residential areas of Itapoá, which includes vacation houses.

Pontal do Norte is the largest fishing community in Itapoá. It is spread out over a large area, located farther from the city center, has little infrastructure and contains a large area of preserved Atlantic Forest. This region has been occupied for many decades as well. The prevalence of European immigrant families makes native species knowledge less expressive than exotic species, despite the wide diversity and availability of native species in the area. A contrasting situation was found at Itapema do Norte. This community is located in the most urbanized and populous area of Itapoá, which includes the city commercial center. 
Table 3. Comparison of cited plants according to age for 90 interviews performed in fishing communities in Itapoá city, Santa Catarina, Brazil.

\begin{tabular}{|c|c|c|c|c|}
\hline & \multicolumn{4}{|c|}{ Age classes } \\
\hline & $18-40$ yrs & $41-50 \mathrm{yrs}$ & $51-60 y r s$ & $61+\mathrm{yrs}$ \\
\hline Average plant richness per interview & $3.17 \pm 1.85$ & $3.76+2.02$ & $4.21 \pm 2.67$ & $5.43 \pm 3.69$ \\
\hline Number of citations & 57 & 79 & 118 & 125 \\
\hline Number of interviews & 18 & 21 & 28 & 23 \\
\hline Number os species cited & 36 & 46 & 55 & 72 \\
\hline Hurlbert's PIE (confidence intervals) & 0.98058 & $0.97414(0.96429-0.98306)$ & $0.97592(0.96554-0.98371)$ & $0.98782(0.98183-0.9931)^{*}$ \\
\hline $\begin{array}{l}\text { Expected richness for the smallest sample } \\
\text { ( } 57 \text { citations) (confidence intervals) }\end{array}$ & 36 & $37(33-41)$ & $35(30-39)$ & $43(38-47)^{*}$ \\
\hline
\end{tabular}

*=significant differences for comparisons with each of all age classes

Table 4. Comparison of cited plants according to community for 90 interviews performed in fishing communities in Itapoá city, Santa Catarina, Brazil.

\begin{tabular}{|c|c|c|c|}
\hline & \multicolumn{3}{|c|}{ Communities } \\
\hline & Barra do Saí & Itapema do Norte & Pontal do Norte \\
\hline Average richness per interview & $1.72 \pm 1.12$ & $2.43 \pm 1.72$ & $2.45 \pm 2.15$ \\
\hline Number of citations & 86 & 85 & 208 \\
\hline Number of interviews & 17 & 31 & 42 \\
\hline Number os species cited & 50 & 35 & 85 \\
\hline Hurlbert's PIE (confidence intervals) & $0,98309(0,98263-0,98403)$ & $0,96891^{*}$ & $0,98397(0,97731-0,98880)$ \\
\hline $\begin{array}{l}\text { Expected richness for a smallest sample ( } 85 \text { citations) } \\
\text { (confidence intervals) }\end{array}$ & $50(46-58)$ & $35^{*}$ & $52(46-58)$ \\
\hline
\end{tabular}

*=significant differences for comparisons with each of all communities

The fishermen are dispersed in the area, and this occupation is declining mostly due to high land values in the region. In this community the small number of citations and species may be a reflection of the younger population as well as the more well-structured public health system (with a health station, an ambulatory, and an emergency room) as well as pharmacies. The distance from native forest and the small number of unmaintained abandoned lots, which concentrate many of the most cited plants, may also influence this result. According to interviewees, the older fishermen are migrating to other fishing communities, for they seem to be more peaceful environments in which to live. Part of knowledge loss may derive from the public health system which is widely used by the community members and replaces home treatment. In several moments the interviewees said to prefer public health treatment as well as prescribed drug medication due to rapid cures. Pinto et al. (2006) emphasized that easy access to the public health system brings greater financial expenditures for medication, as well as the diminished practice of popular medicine. In the communities studied by Voeks \& Leony (2004) medicinal plant knowledge is rapidly disappearing as it is not considered to be as relevant as it was for previous generations. Itapoá city fishing communities may be undergoing a similar process.

The health station physicians stated that they do not prescribe medicinal plants for their patients, although they tolerate and accept their use. However, the presence of public health services close to the communities tends to hinder plant use, which was before the single treatment option available, leading to knowledge loss. All interviewees claim to use health stations not only to cure but also to prevent diseases, administer exams, and for vaccination. This change of habits generates a higher consumption of medication and an appreciation on the part of the population for this kind of treatment, since City Hall provides the majority of the medications prescribed at the health stations. The interviewed physicians additionally mentioned erroneous diagnosis based on symptoms given by the patients, which they consider to be another possible factor in the loss of medicinal plant knowledge. Examples are lower back pains, misinterpreted as kidney infections, and high blood pressure which is considered to be mental stress. Due to the misinterpretations mentioned by the physicians, plants may have been erroneously used in some cases and since the desired effect was not achieved, or the health condition worsened, the plant may have lost credibility regarding its medicinal properties. As a consequence, the information is no longer being transmitted and the plant is no longer being used for medicinal purposes.

Amorozo (2004) reported that in communities in the state of Mato Grosso, medicinal plants are in fact used for the treatment of health problems and indispositions of 
low severity, for they only seek healthcare services when the problem becomes serious. This is probably due to the distance between the community and the health clinic. In Itapoá a similar situation occurs with the use of plants, although the public healthcare services are often used, including in less severe cases. Many of the problems cited as "pains", which are in fact symptoms of another health problem, tend to become more usual with aging. In this case, homemade remedies based on medicinal plants could function only as a palliative, lessening the symptoms and providing the sensation of improvement.

\section{Conclusions}

Medicinal plants are still an important resource utilized for health maintenance of families of the fishing community of Itapoá. Although 36 health problems were cited as frequent, 109 plant species were cited for the treatment of 73 health problems. Public health clinics do attend to the communities but the use of plants to treat less severe health problems is very common. The elderly are still distrusting of industrialized medication and they often switch from commercial medication to medicinal plants in order to treat chronic health problems. Leaves are the most used plant parts, thus plant reproduction is not endangered due to the gathering methods and plant parts used. The most utilized plants were easily found in the area, were available in large quantities, and were in areas of easy access. Cultivation and collection in backyard areas were the main modes of obtaining plants, with no apparent environmental impact or risk for any particular specimen, due to the low utilization of native forest plants when compared to medicinal plant cultivation. Also, there was no exploitation for commercialization.

Several factors influence knowledge and use of medicinal plants in the fishing communities of Itapoá. Among the interviewees, medicinal plant knowledge was similarly distributed for both men and women, but people over 60 years old attain more knowledge of medicinal plants. Also, community location and infrastructure may be interfering with the amount of medicinal plant knowledge.

The most common illnesses were often treated by the conventional system and with industrialized medication, which indicates that there is not great knowledge of medicinal plants to treat the most common ailments suffered by the communities. Medicinal plant knowledge and other traditional knowledge in Itapoá fishing communities were transmitted mostly from the older community members interviewed. However, knowledge transmission seems to be declining due to cultural factors, but mostly due to the extinction of these communities, caused by younger members leaving the communities in pursuit of better life conditions, by urbanization pressures, and the expressive decline of available fish resources.

The Itapoá fishing communities have different characteristics when compared to riverbank or other coastal communities which are more frequently studied by ethnobotanists, due to Amerindian influences on these communities. In Itapoá the Amerindian influence is rather small compared to the influence of European immigrants, mostly Azoreans. Little of the native flora is used and the main medicinal plants come from initial succession environments or abandoned terrain with a low degree of human management.

As communities dwindle due to urbanization, many species will no longer be available as areas are occupied by new development. Also, the use of conventional medication tends to increase and medicinal plant knowledge will lose its functional value and be forgotten, especially by the younger members of these communities. This knowledge is still part of the communities but it was more important in the past. Although still considered important, it is currently being slowly replaced as new and more modern health treatment methods become available.

\section{Acknowledgements}

The authors thank the interviewees and the Plant Biology graduate program at the Federal University of Santa Catarina, as well as Itapoá City Hall. FAPESC (Fundação de Apoio à Pesquisa Científica e Tecnológica de Santa Catarina) provided financial support for this research. N. Hanazaki thanks CNPq (Conselho Nacional de Desenvolvimento Científico e Tecnológico) for her productivity grant.

\section{References}

Almeida, C.F.C.B.R. \& Albuquerque, U.P. 2002. Uso e conservação de plantas e animais medicinais no Estado de Pernambuco (Nordeste do Brasil): um estudo de caso. Interciência 27: 276-285.

Amorozo, M.C.M. 2002. Uso e diversidade de plantas medicinais em Santo Antônio do Leverger, MT, Brasil. Acta Botanica Brasilica 16: 189-203.

Amorozo, M.C.M. 2004. Pluralistic medical settings and medicinal plant use in rural communities, Mato Grosso, Brazil. Journal of Ethnobiology 24: 139-161.

Ayres, M.; Ayres Jr., M.; Ayres, D.L. \& Santos, A.S. 2003. BioEstat 3.0: aplicações estatísticas nas áreas das ciências biológicas e médicas. Belém, Sociedade Civil Mamirauá/CNPq.

Begossi, A.; Hanazaki, N. \& Tamashiro, J.Y. 2002. Medicinal plants and the Atlantic Forest (Brazil): knowledge, use and conservation. Human Ecology 30: 281- 299.

Bennett, B.C. \& Prance, G.T. 2000. Introduced plants in the indigenous pharmacopoeia of Northern South America. Economic Botany 54: 90-102.

Benz, B.F.; Cevallos, E.J.; Santana M.F.; Jesus A.R. \& Graf, M.S. 2000. Losing knowledge about plant use in the Sierra de Manantlan Biosphere Reserve, Mexico. Economic Botany 52: 183-191.

Bourdy, G.; DeWalt, S.J.; Michel, L.R.C.; Roca, A.; Deharo, E.; Muñoz, V.; Balderrama, L.; Quenevo, C. \& Gimenez, A. 2000. Medicinal plants uses of the Tacana, an Amazonian Bolivian ethnic group. Journal of Ethnopharmacology 70: 87-109.

Camou-Guerrero, A.; Reyes-García, V.; Martínez-Ramos, M. \& Casas, A. 2008. Knowledge and use value of plant species in a Rarámuri community: a gender perspective for conservation. Human Ecology 36: 259-272.

Case, R.J.; Pauli, G.F. \& Soejarto, D.D. 2005. Factors in maintaining indigenous knowledge among ethnic communities of Manus island. Economic Botany 59: 356-365. 
Da Silva, C.S.P. \& Proença, C.E.B. 2008. Use and availability of medicinal resources in Ouro Verde de Goiás, Goiás State, Brazil. Acta Botanica Brasilica 22: 481-492.

Di Stasi, L.C.; Oliveira, G.P.; Carvalhaes, M.A.; Queiroz-Junior, M.; Tien, O.S.; Kakinami, S.H. \& Reis, M.S. 2002. Medicinal plants popularly used in the Brazilian Tropical Atlantic Forest. Fitoterapia 73: 69-91.

Figueiredo, G.M.; Leitão-Filho, H.F. \& Begossi, A. 1993. Ethnobotany of Atlantic Forest coastal communities: Diversity of plant uses in Gamboa (Itacuruçá island, Brazil). Human Ecology 21: 419-430.

Figueiredo, G.M.; Leitão-Filho, H.F. \& Begossi, A. 1997. Ethnobotany of Atlantic Forest coastal communities II: Diversity of plant uses at Sepetiba bay (SE Brazil). Human Ecology 25: 353-360.

Fonseca-Kruel, V.S. \& Peixoto, A.L. 2004. Etnobotânica na Reserva Extrativista Marinha de Arraial do Cabo, RJ, Brasil. Acta Botanica Brasilica 18: 177-190.

Friedman, J.; Yaniv, Z.; Dafni, A. \& Palewitch, D. 1986. A preliminary classification of the healing potential of medicinal plants, based on a rational analysis of an ethnopharmacological field survey among Bedouins in the Negev Desert, Israel. Journal of Ethnopharmacology 16: $275-287$.

Gotelli, N.J. \& Entsminger, G.L. 2001. EcoSim: Null models software for ecology. Version 7.0. Acquired Intelligence Inc. \& Kesey-Bear.

Hamilton, A.C. 2004. Medicinal plants, conservation and livelihoods. Biodiversity and Conservation 13: 1477-1517.

Hanazaki, N. 2004. Etnobotânica. Pp. 37-57. In: Begossi, A. (Ed.). Ecologia Humana de Pescadores da Mata Atlântica e da Amazônia. São Paulo, FAPESP/HUCITEC.

Hanazaki, N.; Oliveira, F.C.; Miranda, T.M. \& Peroni, N. 2009. Ethnobotany of Artisanal Fishers. Pp. 104-124. In: P.F.M. Lopes \& A. Begossi (Eds.). Current trends in Human Ecology. Cambridge, Cambridge University Press.

Hanazaki, N.; Tamashiro, J.Y.; Leitão-Filho, H.F. \& Begossi, A. 2000. Diversity of plant uses in two Caiçara communities from Atlantic Forest coast, Brazil. Biodiversity and Conservation 9: 597-615.

Hurlbert, S.H. 1971. The nonconcept of species diversity: a critique and alternative parameters. Ecology 52: 577-585.

IBGE. 2005. Instituto Brasileiro de Geografia e Estatística. IBGE Cidades. www.ibge.gov.br/cidadesat/default.php. Last visited: 18th April 2006.

Lorenzi, H. \& Matos, F.J.A. 2002. Plantas Medicinais no Brasil: nativas e exóticas. Nova Odessa, Instituto Plantarum.

Matavele, J. \& Habib, M. 2000. Ethnobotany in Cabo Delgado, Mozambique: use of medicinal plants. Environment, Development and Sustainability 2: 227-234.
Medeiros, M.F.T.; Fonseca, V.S. \& Andreata, R.H.P. 2004. Plantas medicinais e seus usos pelos sitiantes da Reserva Rio das Pedras, Mangaratiba, RJ, Brasil. Acta Botanica Brasilica 18: 391-399.

Melo, S.; Lacerda, V.D. \& Hanazaki, N. 2008. Espécies de restinga conhecidas pela comunidade do Pântano do Sul, Florianópolis, SC. Rodriguesia 59: 799-812.

Miranda, T.M. \& Hanazaki, N. 2008. Conhecimento e uso de recursos vegetais de restinga por comunidades das ilhas do Cardoso (SP) e de Santa Catarina (SC), Brasil. Acta Botanica Brasilica 22: 203-215.

Pieroni, A. \& Quave, C.L. 2005. Traditional pharmacopoeias and medicines among Albanians and Italians in southern Italy: A comparison. Journal of Ethnopharmacology 101: 258-270.

Pilla, M.A.C.; Amorozo, M.C.M. \& Furlan, A. 2006. Obtenção e uso das plantas medicinais no distrito de Martim Francisco, município de MogiMirim, SP, Brasil. Acta Botanica Brasilica 20: 789-802.

Pinto, E.P.P.; Amorozo, M.C.M. \& Furlan, A. 2006. Conhecimento popular de plantas medicinais em comunidades rurais de mata atlântica Itacaré, BA, Brasil. Acta Botanica Brasilica 20: 751-762.

PNUD. 2000. Programa das Nações Unidas para o Desenvolvimento. www.pnud.org.br/atlas/tabelas/index.php. Acessed: 29th April 2006.

Quinlan, M.B. \& Quinlan, R.J. 2007. Modernization and medicinal plant knowledge in a Caribbean horticultural village. Medical Anthropology Quarterly 21: 169-192.

Rossato, S.C.; Leitão-Filho, H.F. \& Begossi, A. 1999. Ethnobotany of caiçaras of the Atlantic Forest coast, Brazil. Economic Botany 53: 377-385.

Shrestha, P.M. \& Dhillion, S.S. 2003. Medicinal plant diversity and use in the highlands of Dolakha district, Nepal. Journal of Ethnopharmacology 86: 81-96.

Vandebroek, I.; Van Damme, P.; Van Puyvelde, L.; Arrazola, S. \& De Kimpe, N. 2004. A comparison of traditional healers' medicinal plant knowledge in the Bolivian Andes and Amazon. Social Science \& Medicine 59: 837-849.

Voeks, R.A. 1996. Tropical forest healers and habitat preference. Economic Botany 50: 381-400.

Voeks, R.A. 2007. Are women reservoirs of traditional plant knowledge? Gender, ethnobotany and globalization in northeast Brazil. Singapore Journal of Tropical Geography 28: 7-20.

Voeks, R.A. \& Leony, A. 2004. Forgetting the forest: assessing medicinal plant erosion in Eastern Brazil. Economic Botany 58: S294-S306.

Yineger, H.; Yewhalaw, D. \& Teketay, D. 2008. Ethnomedicinal plant knowledge and practice of the Oromo ethnic group in southwestern Ethiopia. Journal of Ethnobiology and Ethnomedicine 4, 11. 